\title{
Description of Anophryoides haemophila n. sp. (Scuticociliatida: Orchitophryidae), a pathogen of American lobsters Homarus americanus
}

\author{
R. J. Cawthorn ${ }^{1, *}$, D. H. Lynn ${ }^{2}$, B. Despres ${ }^{1}$, R. MacMillan ${ }^{1}$, \\ R. Maloney ${ }^{1}$, M. Loughlin ${ }^{3}$, R. Bayer ${ }^{3}$ \\ ${ }^{1}$ Department of Pathology and Microbiology, Atlantic Veterinary College, University of Prince Edward Island, \\ Charlottetown, Prince Edward Island, Canada C1A 4P3 \\ ${ }^{2}$ Department of Zoology, College of Biological Science, University of Guelph, Guelph, Ontario, Canada N1G 2W1 \\ ${ }^{3}$ Department of Animal, Veterinary, and Aquatic Sciences, University of Maine, Orono, Maine 04469-5735, USA
}

\begin{abstract}
The etiological agent of 'bumper car' disease in lobsters Homarus americanus is described as a new species of ciliate, Anophryoides haemophila (Scuticociliatida: Orchitophryidae). A. haemophila $\mathrm{n}$. sp. is distinguished from other species in the genus by the curved rectangular oral polykinetid 2 , a somatic kinety range of 16 to 18 , and its relatively small size. The parasite is easy to maintain in vivo and in vitro for extended periods at 2 to $5^{\circ} \mathrm{C}$. Apparently the ciliate can be a significant impediment to the economic viability of coldwater lobster impoundments in eastern North America. However, factors inducing epizootics of 'bumper car' disease are unknown.
\end{abstract}

KEY WORDS: Anophryoides haemophila American lobster $\cdot$ Homarus americanus Scuticociliatida

\section{INTRODUCTION}

For economic efficiency, crustaceans are highly confined in postcapture and aquaculture situations. In 1993, the lobster fishery had landed values of Can $\$ 294$ million in Canada (Fisheries and Oceans Canada 1994), and of Can $\$ 213$ million in the United States (U.S. Department of Commerce 1994). Although difficult to determine, postharvest losses are estimated at 10 to $15 \%$ annually (Can $\$ 50$ to 75 million). After capture, numerous problems can be associated with intensive and extensive holding systems for lobsters and other crustaceans (Overstreet 1986). In particular, lobster impoundments and other holding facilities can facilitate development of epizootics with subsequent loss of valuable re-sources. Recently, ciliate parasites have gained recognition as etiologic agents of important diseases of crustaceans (Morado \& Small 1995).

'Bumper car' disease, caused by an Anophrys-like ciliate, was first documented from eastern Canada as a

•E-mail: cawthorn@upei.ca pathogen of captive adult and third-stage larval lobsters Homarus americanus held in a flowthrough system at 0 to $10^{\circ} \mathrm{C}$ (Aiken et al. 1973). 'Bumper car' refers to the high activity and rapid motility of the ciliates in vivo and in vitro at cold temperatures. During winter 1971-72, prevalence (via haemolymph examination) of the ciliate was $20 \%$ in market size lobsters from New Brunswick; these lobsters all died within 6 wk. During winter 1972-73, infected adult lobsters from Nova Scotia and Prince Edward Island also died. Additionally, third-stage larval lobsters infected with ciliates died. The 'bumper car' disease problem was apparent from November through March or April in these tankheld, laboratory stocks of lobsters (Aiken et al. 1973). Subsequently, the ciliates were observed during winter months in wild stocks of lobster at cold $\left(0\right.$ to $\left.5^{\circ} \mathrm{C}\right)$ temperatures (Aiken \& Waddy 1986). Details of the numbers of lobsters involved (and mortality rates) in the above studies were not provided (Aiken et al. 1973 Aiken \& Waddy 1986)

More recently, a ciliate mistakenly identified as Mugardia sp. (see Morado \& Small 1994, 1995) caused 
significant mortalities in lobster impoundments of eastern North America (Loughlin \& Bayer 1991, Sherburne \& Bean 1991, Loughlin et al. 1993). Epizootics of 'bumper car' disease were documented in winter and spring in Maine (1990, 1991, 1992) and New Brunswick $(1989,1992,1993)$, with mortalities up to $25 \%$ (Sherburne \& Bean 1991, Loughlin et al. 1993 1994). Additionally, affected lobsters have reduced muscle mass, poorer meat quality and unsavoury flavour (Loughlin et al. 1993). Survivability during shipping can be highly reduced (Sherburne \& Bean 1991). Clinically, 'bumper car' disease is difficult to detect; lobsters can be weak and lethargic, have a 'spread-eagle' posture, and in tidal pounds, have a heavier than normal algal growth on the shell (Loughlin et al 1993). Anecdotally, 'bumper car' disease caused severe losses in some Nova Scotia lobster pounds in 1991 and 1994. Although the prevalence (via haemolymph examination) of ciliates was zero ( $\mathrm{n}=$ 787) in wild-caught Maine lobsters examined from August to December 1992 (Loughlin et al. 1994), our recent (unpublished) observations utilizing a monoclonal antibody directed to the ciliate in a highly sensitive and specific indirect fluorescent antibody test indicate that the parasite occurs in a minimum of $17.8 \%$ $(41 / 230)$ of lobsters from the south shore of Prince Edward Island (fall 1994, spring 1995). Epizootiological factors which determine when ciliate infections progress to 'bumper car' disease in lobsters are unknown.

Our study herein describes this ciliate, Anophryoides haemophila n. sp., from haemolymph of lobsters and in vitro cultures. The parasite was first established from an infected lobster from a Maine lobster pound and transferred from lobster to lobster by intrahaemocoelic inoculation. Ciliates were also maintained in vitro in artificial seawater with frozen lobster muscle, at $5^{\circ} \mathrm{C}$. A. haemophila n. sp., the causative agent of 'bumper car' disease, is easy to maintain in vitro and in vivo in lobsters. The model of 'bumper car' disease should facilitate study of health and infectious disease processes in lobsters, utilizing the holistic approach recently suggested by Stewart (1993).

\section{MATERIALS AND METHODS}

Source and maintenance of ciliates. Lobsters were collected from impoundments in eastern Maine, USA, during winter months; $0.3 \mathrm{ml}$ of haemolymph was removed from a ventral sinus with a 26 -gauge needle on a tuberculin syringe and examined immediately with light microscopy. Lobsters infected with Anophryoides haemophila n. sp. were transported to the University of Maine, Orono, Maine, for further processing.
One $\mathrm{ml}$ of infected haemolymph was put into $50 \mathrm{ml}$ of chilled seawater in a $250 \mathrm{ml}$ tissue culture flask containing $0.1 \mathrm{~g}$ of lobster muscle. Flasks were maintained at 0 to $2^{\circ} \mathrm{C}$.

In March 1993, under permit from Agriculture Canada, culture flasks containing numerous ciliates of A. haemophila n. sp. were transported on ice to the Atlantic Veterinary College (AVC), University of Prince Edward Island, Charlottetown, Prince Edward Island, Canada. At AVC, ciliates were transferred in both $25 \mathrm{~cm}^{2}$ (with $15 \mathrm{ml}$ of sterile artificial seawater) and $75 \mathrm{~cm}^{2}$ (50 $\mathrm{ml}$ of sterile artificial seawater) tissue culture flasks (Corning Inc., Corning, New York 14831, USA). The seawater medium comprised Instant Ocean (Aquarium Systems, Mentor, Ohio 440060, USA) at a salinity of 30 ppt, filter-sterilized with a $0.22 \mu \mathrm{m}$ filter (Corning). Lobster muscle, stored frozen, was thawed and added to cultures, as food for ciliates. Ciliates were washed by centrifugation several times to reduce bacterial contamination prior to inoculation of flasks and subpassaged $(1 \mathrm{ml}$ of infected culture medium into $50 \mathrm{ml}$ of fresh medium prepared as above), every 4 to $6 \mathrm{wk}$. Other cultures were initiated with single ciliates which had been isolated by repeated serial dilution from flask cultures. Cultures were maintained at $5.0 \pm$ $0.1^{\circ} \mathrm{C}$.

Source and maintenance of lobsters. 'Canner' lobsters (carapace length 65.1 to $80.9 \mathrm{~mm}$, weight 190 to $400 \mathrm{~g})$ were purchased during the spring lobster season in Lobster Fishing Area 26A, Prince Edward Island, and transported to the Aquatic Animal Facility, AVC. Lobsters were held in a 6 -tank, $4700 \mathrm{l}$ capacity, saltwater recirculation system that was equipped with both particle and biological filtration. Artificial salt water was prepared from Instant Ocean. Each tank housed 20 lobsters (all claws banded) in individual compartments in 2 stacked trays. Water quality was monitored weekly for unionized ammonia (to be $<0.01 \mathrm{mg} \mathrm{l}^{-1}$ ), nitrate ion levels (to be $<20.0 \mathrm{mg} \mathrm{l}^{-1}$ ), nitrite ion (to be $<0.1 \mathrm{mg} \mathrm{l}^{-1}$ ), $\mathrm{pH}$ (range 7.9 to 8.4 ), and salinity (range 29 to $30 \mathrm{ppt}$ ), and continuously for temperature $\left(2 \pm 1^{\circ} \mathrm{C}\right)$. Lobsters were fed weekly, one blue mussel Mytilus edulis with a cracked shell per lobster, and the system was monitored daily for ill or dead lobsters. Lobsters were maintained in accordance with Guidelines of the Canadian Council on Animal Care. on a $12 \mathrm{~h}$ light: $12 \mathrm{~h}$ dark photoperiod.

Observation and staining of ciliates. Live ciliates from both lobster haemolymph and cultures were studied with phase-contrast and differential interference contrast microscopy. Smears of ciliates were made either with fresh haemolymph of experimentally infected lobsters or with ciliates grown in vitro. The latter were washed by centrifugation ( $150 \times g$ for $5 \mathrm{~min}$ ), mixed with mucus from mussel gill (to ensure adhesion 
to glass coverslips) and smeared on clean glass cover slips. All smears were fixed immediately by floating cover slips on fresh Bouin fixative in a Petri dish. Protargol staining (protargol-silver protein) (Roboz Surgical Instrument Co., Inc., Rockville, Maryland 20850, USA) followed the method of Lee et al. (1985); subsequently, cover slips were mounted on glass slides with Flo-texx mounting medium (Lerner Laboratories, Pittsburgh, Pennsylvania 15275, USA). Measurements were made from fixed ciliates utilizing an eyepiece micrometer. Descriptive terminology for the parasite followed Corliss \& Lom (1985) and Small \& Lynn (1985).

\section{RESULTS}

\section{Anophryoides haemophila n. sp. (Fig. 1)}

Diagnosis. Oral polykinetid 1 about $4 \mu \mathrm{m}$ in length, triangular, composed of at least 3 kinetosomes at posterior margin and a single kinetosome at anterior. Oral polykinetid 2 about $5 \mu \mathrm{m}$ long, curved rectangular,

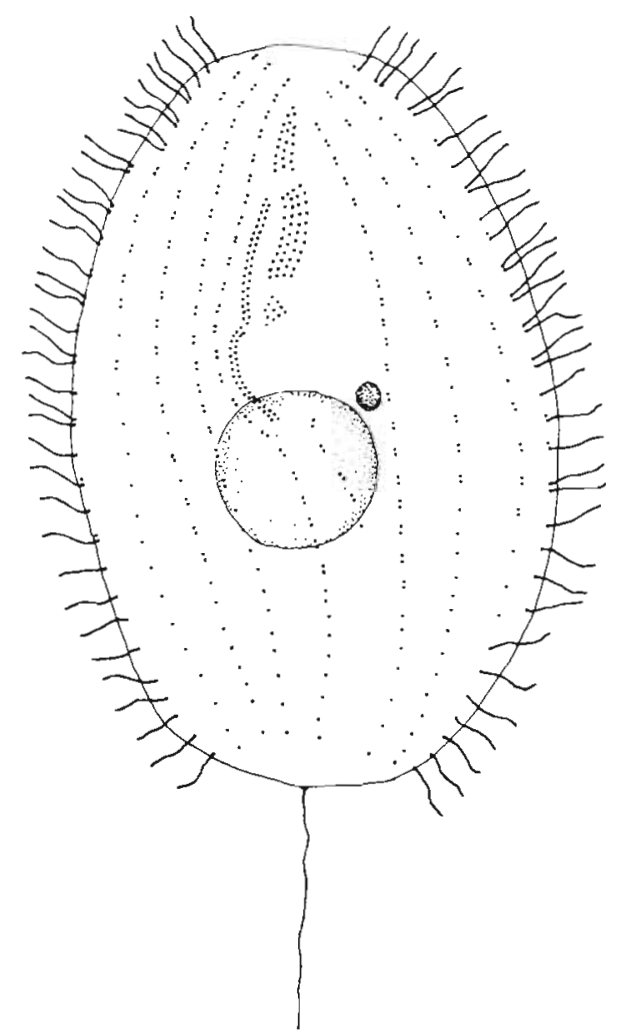

Fig. 1. Anophryoides haemophila n. sp. Schematic drawing based on protargol-stained specimens. Note that the more elongate, pointed shape of the living cells (cf. Fig. 2) is altered by Bouin fixation and protargol staining to the more blunted form illustrated here (cf. Fig. $3 \& 4$ ). Scale bar $=5.0 \mu \mathrm{m}$ usually composed of 4 files of kinetosomes. Oral polykinetid 3 triangular to square on anterior wall of oral cavity. Paroral extends from anterior end of oral polykinetid 2 to the level of oral polykinetid 3 and then curves along the right side of the oral cavity depression.

Type location. Gulf of Maine, Maine, USA. $44^{\circ}$ $33^{\prime} \mathrm{N}, 68^{\circ} 25^{\prime} \mathrm{W}$.

Type specimen. A slide containing the holotype (USNM 47825) from lobster haemolymph was deposited in the Ciliate Type Slide Collection, National Museum of Natural History, Smithsonian Institution, Washington, DC 20560, USA.

Etymology. The species name refers to the apparent preference this ciliate has for lobster haemolymph and haemocytes.

Description. Anophryoides haemophila n. sp. is an elongate ovoid scuticociliate (Figs. $2 \& 3$ ). Body length $34.8 \pm 3.2 \mu \mathrm{m}$ (25.5 to $41.0, \mathrm{n}=32$ ) from lobster haemolymph; body length $25.5 \pm 2.5 \mu \mathrm{m}$ (21.8 to $31.9 \mu \mathrm{m}$ $\mathrm{n}=33$ ) in culture. Body width $22.6 \pm 3.1 \mu \mathrm{m}$ (14.6 to $27.3 \mu \mathrm{m}, \mathrm{n}=32$ ) from lobster haemolymph; body width $14.2 \pm 2.5 \mu \mathrm{m}(7.3$ to $19.1 \mu \mathrm{m}, \mathrm{n}=33)$ in culture.

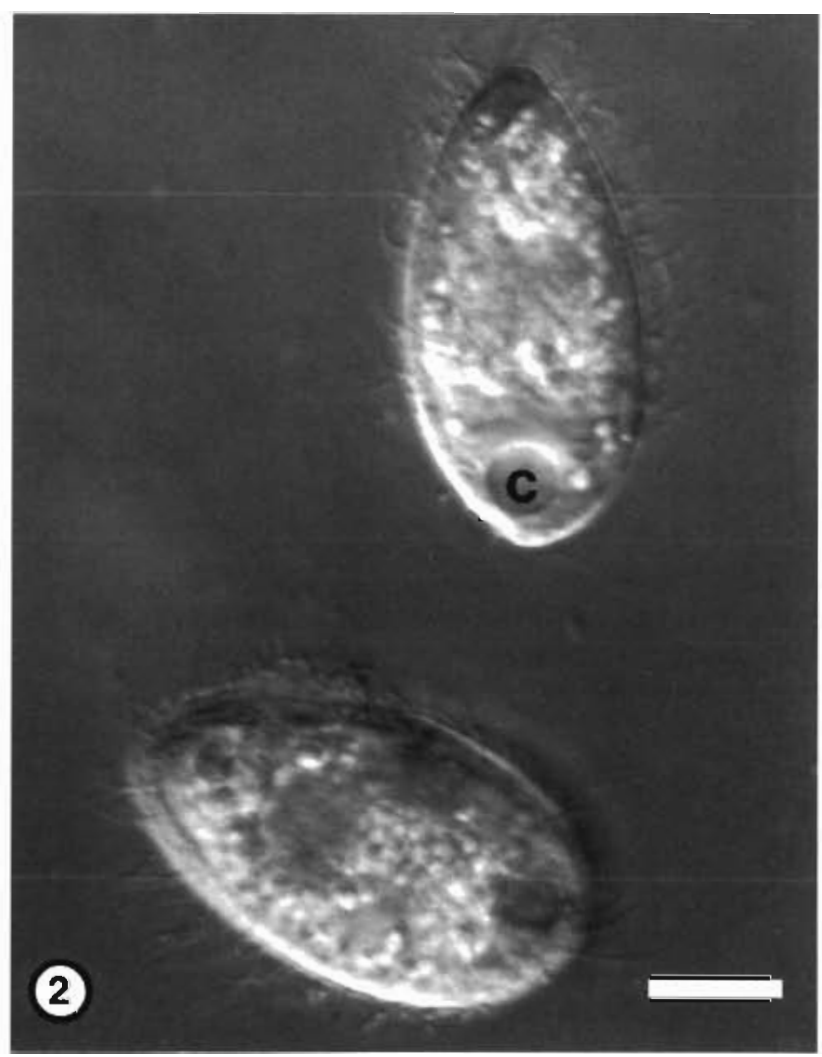

Fig. 2. Anophryoides haemophila n. sp. Live specimens, in haemolymph of experimentally infected lobster. C: contractile vacuole. Differential interference contrast microscopy. Scale $\mathrm{bar}=10.0 \mu \mathrm{m}$ 


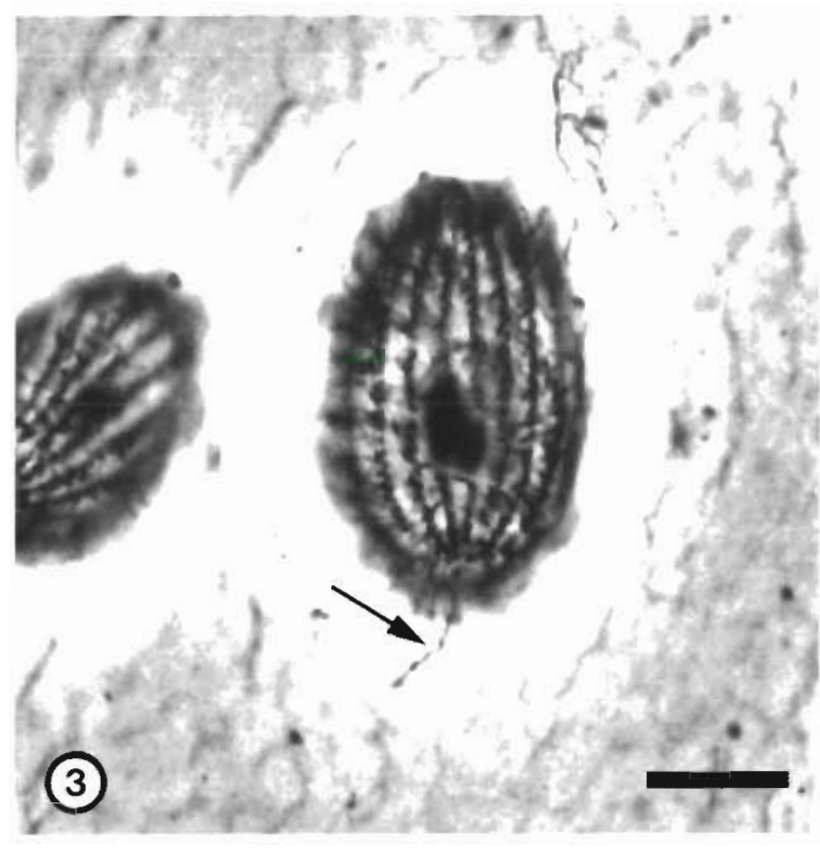

Fig. 3. Anophryoides haemophila n. sp. Overview of Bouinfixed specimen, in haemolymph of experimentally infected lobster. Protargol stain. Note caudal cilium (arrow). Scale bar $=10.0 \mu \mathrm{m}$

The oral region is elongate and restricted to the anterior half (Fig. 4). Posterior to oral polykinetid 2, the oral region forms an oral cavity depression at the bottom of which is the cytostome. Oral region length $18.1 \pm$ $1.4 \mu \mathrm{m}(15.5$ to $21.8 \mu \mathrm{m}, \mathrm{n}=30)$ from lobster haemolymph. Oral polykinetid 1 is triangular, composed of at least 3 kinetosomes at its posterior margin and tapering to a single kinetosome at its anterior end. Oral polykinetid 1 length $3.8 \pm 0.4 \mu \mathrm{m}(3.2$ to $4.6 \mu \mathrm{m}, \mathrm{n}=23)$ from lobster haemolymph. Oral polykinetid 2 is curved rectangular, usually composed of 4 files of kinetosomes. Oral polykinetid 2 length $5.2 \pm 0.6 \mu \mathrm{m}$ (4.6 to $6.4 \mu \mathrm{m}, \mathrm{n}=23$ ) from lobster haemolymph. Oral polykinetid 3 is triangular to square and is placed on the anterior wall of the oral cavity depression. The paroral kinety is composed of dikinetids that zig-zag along their length, beginning near the anterior end of oral polykinetid 2 . The paroral extends from the anterior end of oral polykinetid 2 to the level of oral polykinetid 3 and then forms a curve along the right side of the oral cavity depression. The scutica forms a short file, usually of dikinetids, that extends between somatic kineties 1 and $n$.

Somatic kineties, 16 to $18(n=48)$, extend from the anterior pole to just anterior to the posterior pole. The anterior half of each somatic kinety is composed of dikinetids that commonly have both kinetosomes ciliated. A prominent caudal cilium, about $15 \mu \mathrm{m}$ long,

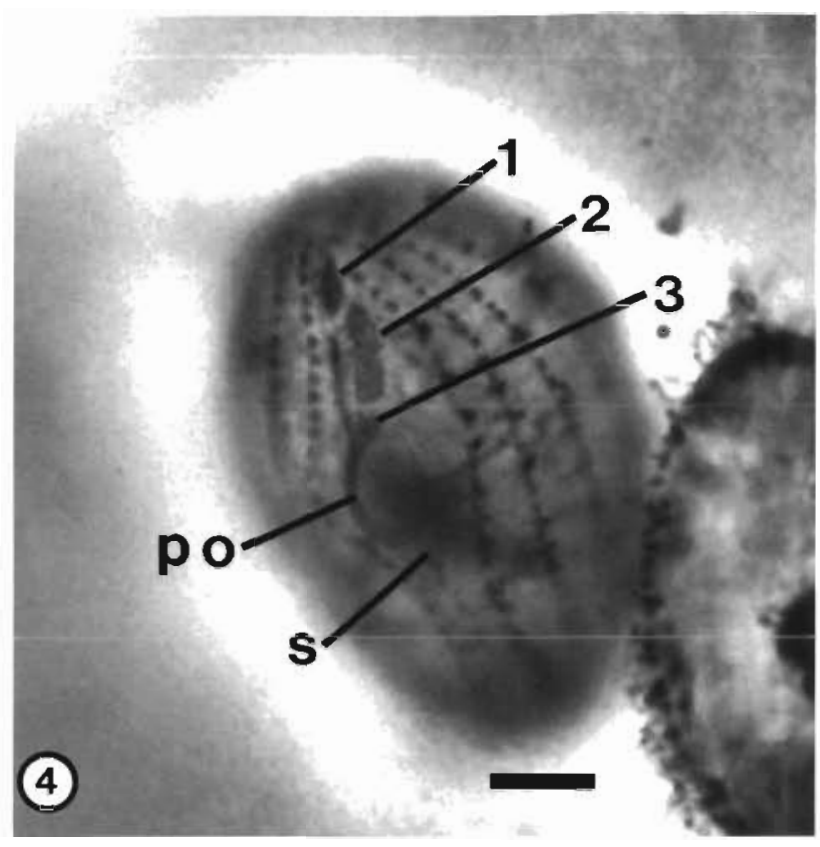

Fig. 4. Anophryoides haemophila n. sp. Details of oral ciliature of Bouin-fixed specimen, in haemolymph of experimentally infected lobster. Protargol stain. Scale bar $=5.0 \mu \mathrm{m}$. 1: oral polykinetid $1 ; 2$ : oral polykinetid $2 ; 3$ : oral polykinetid 3 ; po: parorali s: sculica

arises from the posterior pole. There is a single contractile vacuole that opens through 1 or 2 contractile vacuole pores, located at the posterior end of somatic kineties 1,2 or 3 .

The macronucleus is almost spheroid. Macronuclear length $8.4 \pm 1.3 \mu \mathrm{m}(6.4$ to $11.8 \mu \mathrm{m}, \mathrm{n}=32)$ from lobster haemolymph; macronuclear length $6.8 \pm 1.1 \mu \mathrm{m}$ (5.5 to $9.1 \mu \mathrm{m}, \mathrm{n}=31$ ) in culture. Macronuclear width $6.4 \pm$ $1.1 \mu \mathrm{m}$ (4.6 to $9.1 \mu \mathrm{m}, \mathrm{n}=32$ ) from lobster haemolymph; macronuclear width $5.5 \pm 0.8 \mu \mathrm{m}$ (4.6 to $7.3 \mu \mathrm{m}$, $\mathrm{n}=27$ ). Spheroid micronucleus, single, usually closely adjacent to the macronucleus. Micronuclear diameter $1.76 \pm 0.16 \mu \mathrm{m}(1.37$ to $1.82, \mathrm{n}=22)$ from lobster haemolymph

\section{DISCUSSION}

Anophryoides was established as a genus by de Puytorac \& Grolière (1979) for a ciliate originally described by Mugard (1949). Anophryoides haemophila n. sp. is placed in the genus Anophryoides primarily because the paroral begins near the anterior end of oral polykinetid 2 and oral polykinetids 1 and 2 are of similar length (Small \& Lynn 1985). Morado \& Small (1994) have provided a description of paranophryid ciliate genera with their description of Mesanophrys pugettensis, a ciliate that causes mortality in 
Cancer magister, and reviewed the distinguishing characteristics of the different genera.

Prior to 1985, Anophryoides was a monotypic genus. At this time, Small \& Lynn (1985) briefly described $A$. soldoi and provided $A$. puytoracias a new name for $A$. salmacida de Puytorac \& Grolière 1979. Subsequently, Strüder \& Wilbert (1992) transferred Paranophrys carnivora Czapik \& Wilbert, 1986, to the genus Anophryoides. With the addition of A. haemophila n. sp., there are now 4 species in the genus, as we now regard $A$. puytoraci to be a junior synonym of $A$. salmacida. Anophryoides is a bacterivorous species that can be maintained in an axenic medium (E. B. Small pers. comm.). However, A. salmacida and A. carnivora are both reported to be histophages that were fed in culture on tissues of invertebrates (Czapik \& Wilbert 1986) or vertebrates (de Puytorac \& Grolière 1979). These authors did not indicate what these species prefer as food in nature. A. haemophila n. sp. can be grown on autoclaved lobster tissue. However, this is apparently a minimal medium, since its cell size (see above) and growth rate (unpubl. obs.) are increased when the parasite infects the lobster host.

Anophryoides soldoi differs from the other 3 species in having its contractile vacuole just posterior to the paraoral rather than near the posterior end of the cell. A. haemophila $\mathrm{n} . \mathrm{sp}$. is distinguished from A. salmacida and $A$. carnivora primarily by the length of the oral polykinetids, which are smaller: oral polykinetid 1 about $4 \mu \mathrm{m}$ compared to 6 to $8 \mu \mathrm{m}$ and oral polykinetid 2 about $5 \mu \mathrm{m}$ compared to 9 to $11 \mu \mathrm{m}$ (see Strüder \& Wilbert 1992). It also has fewer somatic kineties, 16 to 18 compared to between 21 and 22. A. haemophila $\mathrm{n}$. sp. is shorter than $A$. salmacida (25.5 to $41.0 \mu \mathrm{m}$ vs 55 to $85 \mu \mathrm{m})$, but overlaps in cell length with $A$. carnivora (25.5 to $41.0 \mu \mathrm{m}$ vs 35 to $56 \mu \mathrm{m}$ ). Thus, it can be distinguished from $A$. salmacida by its shorter cell length, shorter oral polykinetids, and smaller number of somatic kineties, and from $A$. carnivora by the latter 2 features. On these grounds, this new species is justified.

Currently, we do not know whether Anophryoides haemophila $\mathrm{n}$. $\mathrm{sp}$. shows host specificity only for the American lobster Homarus americanus. The parasite does retain its infectivity and pathogenicity to lobsters although maintained for long periods $(>12 \mathrm{mo}$ ) in vitro (unpubl. obs.). Overall, use of A. haemophila n. sp. as a model of 'bumper car' disease should facilitate elucidation of health and infectious disease processes in lobsters and related crustaceans.

Acknowledgements. Project funding at the University of Prince Edward Island was a subcontract from the Canadian Atlantic Lobster Promotion Association (CALPA). CALPA was supported, in part, by the Industrial Research Assistance Program of the National Research Council of Canada. R.J.C. and
D.H.L. were the recipients of Research Grants from the Natural Sciences and Engineering Research Council of Canada.

\section{LITERATURE CITED}

Aiken DE, Sochasky JB, Wells PG (1973) Ciliate infestation of the blood of the lobster, Homarus amencanus. Comm Meet Int Coun Explor Sea - Shellfish and Benthos Committee CM-ICES 1973/K:46

Aiken DE, Waddy SL (1986) Environmental influence on recruitment of the American lobster, Homarus americanus: a perspective. Can J Fish Aquat Sci 43:2258-2270

Corliss JO, Lom J (1985) An annotated glossary of protoz.oological terms. In: Lee JJ, Hutner SH, Bovee EC (eds) An illustrated guide to the Protozoa. Society of Protozoologists, Lawrence, KS, p 576-602

Czapik A, Wilbert N (1986) Sur une nouvelle espèce de cilié Paranophrys carnivora sp. n. (Scuticociliatida). Acta Protozool 25:427-432

de Puytorac P, Grolière CA (1979) Sur le cilié Anophryoides salmacida (Mugard, 1949) nov. gen. Protistologica 15 $223-230$

Fisheries and Oceans Canada (1994) Canadian fisheries Landings, December 1994, Vol 16, No 4. Department of Fisheries and Oceans Canada

Lee JJ, Small EB, Lynn DH, Bovee EC (1985) Some techniques for collecting, cultivating and observing protozoa. In: Lee JJ, Hutner SH, Bovee EC (eds) An illustrated guide to the Protozoa. Society of Protozoologists, Lawrence, KS, p 1-7

Loughlin MB, Bayer RC (1991) Scanning electron microscopy (SEM) of Mugardia, formerly Anophrys, a pathogenic protozoan of the American lobster J Shellfish Res 10:298 (Abstract)

Loughlin MB, Bayer RC, Prince DL (1993) Ciliated protozoan disease in lobster, Homarus americanus. Irish-American Technical Exchange on the Aquaculture of Abalone, Sea Urchins, Lobsters and Kelp. Connecticut Sea Grant College Program. CT-SG-93-05, p 65-67

Loughlin MB, Bayer RC, Prince DL (1994) Incidence of ciliated protozoans in feral lobsters (Homarus americanus). Bull Aquacult Ass Can 94-1:49-51

Morado JF, Small EB (1994) The morphology and stomatogenesis of Mesanophrys pugettensis $\mathrm{n}$. sp. (Scuticociliatida Orchitophryidae), a facultative parasitic ciliate of the Dungeness crab, Cancer magister (Crustacea: Decapoda) Trans Am Microsc Soc 113:343-364

Morado JF, Small EB (1995) Ciliate parasites and diseases of Crustacea: a review. Rev Fish Sci 3:275-354

Mugard H (1949) Contribution à l'étude des infusoires hyménostomes histophages. Ann Sci Naturelles, Zool Biol Anim 10:171-268

Overstreet RM (1986) Solving parasite-related problems in cultured Crustacea. In: Howell MJ (ed) Proceedings of the Sixth International Congress of Parasitology. Australian Academy of Science, Canberra, p 309-318

Sherburne SW, Bean LL (1991) Mortalities of impounded and feral lobsters, Homarus americanus H. Milne-Edwards 1837, caused by the protozoan ciliate Mugardia (formerly Anophrys = Paranophrys), with initial prevalence data from ten locations along the Maine coast and one offshore area. J Shellfish Res 10:315-326

Small EB, Lynn DH (1985) Phylum Ciliophora Doflein, 1901 In: Lee JJ, Hutner SH, Bovee EC (eds) An illustrated guide to the Protozoa. Society of Protozoologists, Lawrence, KS p $393-575$

Stewart JE (1993) Infectious diseases of marine crustaceans 
In: Couch JA, Fournie JW (eds) Pathobiology of marine and estuarine organisms. Advances in Fisheries Science. CRC Press, Boca Raton, FL, p 319-342

Struider M, Wilbert N (1992) Contrzbution to the taxonomy of

Responsible Subject Editor: J. E. Stewart, Dartmouth, Nova Scotia, Canada the family Paranophryidae Jankowski in Small and Lynn, 1985. Acta Protozool 31:33-37

US Department of Commerce (1994) Fisheries of the United States, 1993. Current Fishery Statistics No 9300

Manuscript first received: June 8, 1995

Revised version accepted: August 23, 1995 